\title{
RANCANG BANGUN APLIKASI TRACER MEDICAL RECORD FILE BERBASIS HYPERTEXT PREPROCESSOR DI RUMAH SAKIT UMUM DAERAH (RSUD) WANGAYA KOTA DENPASAR
}

\author{
Ni Ketut Amylia Pramasari ${ }^{1)}$ Bambang Hadi Kartiko ${ }^{2)}$ \\ Gerson Feoh $^{3)}$ \\ Program Studi Perekam dan Informasi Kesehatan ${ }^{12)}$ \\ Program Studi Teknik Informatika ${ }^{2}$ \\ Fakultas Ilmu Kesehatan Sains dan Teknologi, Universitas Dhayan Pura, Badung,Bali 1) 2) 3) \\ tereori21@gmail.com ${ }^{1)}$ gerson.feoh@undhirabali.ac.id ${ }^{2)}$
}

\section{ABSTRACT}

Rumah Sakit Umum Daerah (RSUD) Wangaya of Denpasar City has not used tracer yet to process and take the medical record. The lending book or expedition book that has function record subject, quantity and time of medical record movement, is not available in the medical record instalation. According the earlier records that was hold in Rumah Sakit Umum Daerah (RSUD) Wangaya of Denpasar city on May-June 2016, it has been knowing that 22.3\% medical record has been missfiled. It consist 867 from 3.950 medical record. That case cause dropout of medical record. Rumah Sakit Umum Daerah (RSUD) Wangaya of Denpasar City needs an integrated application and it can be used to coordinate medical record distribution between medical record department staff and polyclinic staff. The goal of this research is to design and develop a medical record file tracer application based on hypertext preprocessor to help staff to trace the medical record. This application is developed with PHP programming language and MySQL as the database server. Development of this system used System Development Life Cycle (SDLC) method. The Medical Record File Tracer Application Based On Hypertext Preprocessor is hoped to help the medical record department staff and polycilinic staff to trace and monitors the medical record patient. Keyword : Medical record, file tracer, php, filing, medical record drop out.

\begin{abstract}
ABSTRAK
Rumah Sakit Umum Daerah (RSUD) Wangaya Kota Denpasar belum menggunakan tracer dalam proses pengambilan rekam medis. Buku peminjaman atau buku ekspedisi yang berfungsi untuk mencatat siapa dan berapa jumlah rekam medis yang dipinjam serta tanggal rekam medis dipinjam tidak tersedia di instalasi rekam medis. Berdasarkan studi pendahuluan yang dilakukan di Rumah Sakit Umum Daerah (RSUD) Wangaya Kota Denpasar pada bulan Mei-Juni 2016 diketahui jumlah kejadian missfile sebanyak 867 rekam medis dari 3.950 rekam medis dengan tingkat persentase mencapai $22.3 \%$. Hal ini menyebabkan terjadinya dropout rekam medis.Rumah Sakit Umum Daerah (RSUD) Wangaya Kota Denpasar membutuhkan aplikasi yang terintegrasi dan dapat digunakan untuk koordinasi distribusi rekam medis antara petugas rekam medis dan petugas poli. Tujuan penelitian ini adalah menghasilkan rancang bangun aplikasi tracer medical record file berbasis hypertext preprocessor (PHP) untuk mempermudah petugas melakukan proses pelacakan dan monitoring rekam medis. Aplikasi ini dikembangkan dengan bahasa pemrograman PHP dan MySQL sebagai database server. Pengembangan aplikasi ini menggunakan metodelogi System Development Life Cycle (SDLC). Aplikasi medical record file berbasis hypertext preprocessor
\end{abstract}


diharapkan dapat membantu petugas rekam medis untuk melacak dan memonitoring rekam medis pasien.

Kata kunci : Rekam medis, file tracer, php, filing , dropout rekam medis

\section{PENDAHULUAN}

Sistem informasi telah berkembang seiring dengan perkembangan teknologi informasi yang sangat cepat dan telah terbukti berperan dalam berbagai kegiatan. Keberadaan sistem informasi mendukung kinerja peningkatan efisiensi, efektivitas dan produktivitas bagi berbagai instansi, baik instansi pemerintahan negeri, swasta maupun perorangan atau individual. Sektor kesehatan yang merupakan salah satu sektor penting yang sedang mendapat perhatian besar dari pemerintah (Heryanto, 2010).

Rumah sakit adalah bagian terpenting dari suatu sistem kesehatan karena rumah sakit merupakan sarana kesehatan yang berfungsi sebagai tempat pengobatan berbagai penyakit dan trauma, dan juga sudah berfungsi sebagai sarana untuk pencegahan, promosi kesehatan dan rehabilitasi (Sukaesih, 2008). Rumah sakit sebagai salah satu fasilitas pelayanan kesehatan diwajibkan untuk membuat rekam medis, hal ini tercantum pada Permenkes No. 269/MENKES/PER/III/2008. Rekam medis adalah berkas yang berisi catatan dan dokumen tentang identitas pasien, pemeriksaan, pengobatan, tindakan dan pelayanan lain kepada pasien pada sarana pelayanan kesehatan (Permenkes RI No. 55 Tahun 2013).

Pelayanan rekam medis yang baik dan bermutu tercermin dari pelayanan yang ramah, cepat, serta nyaman. Pelayanan rekam medis rawat jalan dimulai dari tempat pendaftaran pasien sampai memperoleh rekam medis yang akan digunakan untuk mendapatkan pelayanan kesehatan. Berdasarkan standar pelayanan minimal rumah sakit disebutkan bahwa penyediaan rekam medis pelayanan rawat jalan adalah 10 menit, dan penyediaan rekam medis pelayanan rawat inap selama 15 menit (Menkes RI, 2008).

Berdasarkan studi pendahuluan yang dilakukan di Rumah Sakit Umum Daerah (RSUD) Wangaya Kota Denpasar pada bulan Mei-Juni 2016 diketahui jumlah kejadian missfile (salah letak) sebanyak 879 rekam medis dari 3.950 dengan tingkat persentase mencapai $22.3 \%$. Tracer sebagai kartu pelacak rekam medis yang keluar dari rak penyimpanan masih bersifat manual, dari kertas dan digunakan berkali-kali. Buku ekspedisi atau buku peminjaman rekam medis tidak tersedia di instalasi rekam medis. Buku ekspedisi berfungsi untuk mencatat siapa dan berapa jumlah rekam medis yang dipinjam, serta tanggal rekam medis dipinjam. Tidak adanya buku ekspedisi dan penggunaan tracer kertas tidak membantu petugas rekam medis untuk melacak keberadaan rekam medis, hal ini menyebabkan terjadinya drop out rekam medis. Menurut kepala instalasi rekam medis di Rumah Sakit Umum Daerah (RSUD) Wangaya Kota Denpasar rekam medis drop out merupakan rekam medis yang tidak ditemukan pada saat dibutuhkan atau saat pasien berobat ke rumah sakit. Angka drop out rekam medis berjumlah 162 rekam medis. Drop out terjadi oleh karena petugas kurang disiplin dalam menyimpan kembali rekam medis yang keluar dari rak penyimpanan. Monitoring rekam medis yang keluar dari rak penyimpanan sulit dilakukan karena tidak ada pencatatan rekam medis yang keluar dan masuk di bagian filing rekam medis.

Diperlukan suatu aplikasi yang dapat digunakan sebagai alat bantu untuk mempermudah proses pelacakan rekam medis yang keluar dan masuk di Rumah Sakit Umum Daerah (RSUD) Wangaya Kota Denpasar. Perancangan program aplikasi PHP berbasis web di rumah sakit ini dimaksudkan untuk memberikan informasi mengenai keberadaan rekam medis pasien, sehingga dapat mengurangi angka missfile, drop out rekam medis pasien, dan melacak rekam medis pasien di Rumah Sakit Umum Daerah (RSUD) Wangaya Kota Denpasar.

\section{TINJAUAN PUSTAKA \\ Rumah Sakit}

Rumah sakit adalah institusi pelayanan kesehatan yang menyelenggarakan pelayanan kesehatan perorangan secara paripurna yang menyediakan pelayanan rawat inap, rawat jalan, dan gawat darurat (Permenkes RI No 56 Tahun 2014).

\section{Pengertian Rekam Medis}

Rekam Medis adalah "berkas yang berisi catatan dan dokumen tentang identitas pasien, pemeriksaan, pengobatan, tindakan dan pelayanan lain kepada pasien pada fasilitas pelayanan kesehatan" (Permenkes RI No 55 Tahun 2013).

Rekam Medis yaitu "berkas yang berisi catatan dan dokumen antara lain identitas 
pasien, hasil pemeriksaan, pengobatan yang telah diberikan, serta tindakan dan pelayanan lain yang telah diberikan kepada pasien" (Permenkes No: 269/MENKES/PER/III/2008).

\section{Petunjuk Keluar (Outguide) atau Tracer}

Petunjuk keluar adalah suatu alat yang penting untuk mengawasi penggunaan rekam medis. Dalam penggunaanya petunjuk keluar diletakkan sebagai pengganti pada tempat rekam medis yang diambil (dikeluarkan) dari rak penyimpanan. Kartu pinjam/petunjuk keluar tetap berada di rak filing sampai rekam medis yang diambil (dipinjam) kembali ke tempat semula (Depkes RI, 2006).

Menurut International Federation of Health Information Management Associations (IFHIMA, 2012), tracer (outguide) adalah pengganti rekam medis yang dikeluarkan dari penyimpanan untuk tujuan apapun. Petunjuk keluar meningkatkan efisien dan keakuratan dalam peminjaman dengan menunjukkan dimana sebuah rekam medis untuk disimpan saat kembali. Ketika penyimpanan kembali, slip permintaan akan dihapus dan tersedia, kosong dari slip peminjaman pada catatan (Utami, 2016).

\section{Pendistribusian Rekam Medis}

Pendistribusian rekam medis adalah proses pengiriman rekam medis menuju poliklinik. Distribusi rekam medis dilakukan berdasarkan permintaan pasien di tempat pendaftaran pasien menuju poliklinik yang diinginkan. Standar pelayanan minimal untuk waktu pendistribusian/penyediaan rekam medis pelayanan rawat jalan kurang dari atau sama dengan 10 menit ( $\leq 10$ menit), sedangkan untuk waktu pelayanan rawat inap kurang dari atau sama dengan 15 menit $(\leq 15$ menit) (Kepmenkes RI No. 129/Menkes/SK/II/2008).

\section{Sistem Informasi Manajemen Rumah Sakit}

Sistem informasi manajemen rumah sakit (SIMRS) adalah suatu sistem teknologi informasi komunikasi yang memproses dan mengintegrasikan seluruh alur proses pelayanan rumah sakit dalam bentuk jaringan koordinasi, pelaporan dan prosedur administrasi untuk memperoleh informasi secara tepat dan akurat, dan merupakan bagian dari sistem informasi kesehatan (Permenkes No.82 Tahun 2013).

Peran sistem informasi didalam kegiatan manajemen rumah sakit sangat membantu dan mempunyai peran yang efektif dalam proses pelayanan kesehatan di rumah sakit, dengan sistem informasi seorang pemimpin rumah sakit dapat mengambil suatu kebijakan secara cepat, tepat, dan akurat berdasarkan informasi yang didapat dari pelayanan kesehatan yang dipimpinnya (Rustiyanto, 2010).

\section{Browser}

Browser merupakan sebuah program yang digunakan untuk menampilkan halaman web. Browser dirancang untuk mengambil informasi-informasi dari suatu server komputer pada jaringan internet. Untuk mengakses web diperlukan suatu program yaitu web browser (Sutarman, 2007).

\section{Definisi PHP}

PHP (Hypertext Preprocessor) merupakan skrip yang bersifat server site dimana proses pengerjaan skripnya berlangsung di server. Dengan menggunkan PHP maka perawatan suatu situs web akan menjadi lebih mudah. PHP pertama kali ditemukan oleh Rasmus Lerdoff. Penulisan skrip PHP tersebut dengan cara disisipkan pada HTML. PHP merupakan bahasa pemograman yang digunakan untuk membangun aplikasi-aplikasi berbasis web khususnya aplikasi web yang bersifat dinamis (Sulhan, 2006).

PHP dirancang untuk membentuk aplikasi web dinamis. Artinya, ia dapat membentuk suatu tampilan berdasarkan permintaan terkini. Misalnya, kita dapat menampilkan isi database ke halaman web. Pada prinsipnya PHP mempunyai fungsi yang sama dengan skrip-skrip seperti ASP (Active Server Page). Artinya, skrip PHP dapat dijalankan tanpa melibatkan web server maupun browser (Kadir, 2003).

\section{JavaScript}

JavaScript adalah bahasa script berdasarpada objek yang memperbolehkan pemakai untuk mengendalikan banyak aspek interaksi pemakai pada suatu dokumen HTML. Objek tersebut dapat berupa suatu windows, frame, URL, dokumen, form, button, atau item yang lain. Terdapat dua piranti yang diperlukan dalam JavaSricpt yaitu browser dan texteditor. Text editor adalah sebuah pengolah kata (word processor) yang menghasilkan file dalam format ASCII murni (Suryana dkk, 2014).

\section{Definisi HTML}

HTML (Hyper Text Markup Language) adalah suatu format data yang digunakan 
untuk membuat dokumen hypertext yang dapat dieksekusi dari satu platform komputer ke platform komputer lainya tanpa perlu melakukan suatu perubahan apapun dengan suatu alat tertentu (Junaedi, 2005).

HTML (Hypertext Markup Language) yaitu salah satu bahasa scripting yang dapat menghasilkan halaman website sehingga halaman tersebut dapat diakses pada setiap komputer pengakses (client). Dokumen HTML merupakan dokumen yang disajikan dalam browser web surfer. Dokumen ini umumnya berisi informasi ataupun interface aplikasi dalam internet (Sidik, 2002).

\section{Definisi CSS}

CSS (Cascading Style Sheets) banyak digunakan untuk memperluas kemampuan HTML dalam memformat dokumen web atau untuk mempercantik tampilan bahkan untuk memposisikan dan layouting halaman web. Dengan mendefinisikan suatu style sekali saja maka style itu akan digunakan berulang kali. (Suyanto, 2006).

\section{Database}

Database atau basis data adalah suatu pengorganisasian sekumpulan data yang saling terkait sehingga memudahkan aktivitas untuk memperoleh informasi (McLeod dan Schell, 2008). Database merupakan kumpulan dari data yang saling berhubungan dengan data lainnya, tersimpan diperangkat keras komputer dan digunakan perangkat lunak untuk memanipulasinya, diantaranya; data, user dan sistem (Kadir, 2003).

\section{SDLC System Development Life Cycle}

SDLC System Development Life Cycle atau siklus hidup pengembangan sistem adalah aplikasi dari pendekatan sistem bagi pengembangan suatu sistem informasi. Tidak dibutuhkan waktu lama bagi seorang pengembangan sistem yang pertama untuk mengetahui bahwa terdapat beberapa tahapan pekerjaan pengembangan yang perlu dilakukan dalam urut-urutan tertentu jika suatu proyek ingin memiliki kemungkinan berhasil yang paling besar. Tahapan-tahapan tersebut adalah:

1. Perencanaan, bertujuan untuk mengidentifikasi skup dari sistem baru, menjamin proyek agar visible, dan membuat jadwal, perencanaan sumber daya, dan anggaran yang dibutuhkan dalam pelaksanaan proyek.

2. Analisis, bertujuan untuk memahami dan mendokumentasikan detail dari kebutuhan bisnis dan kebutuhan proses dari sistem baru.
3. Desain, bertujuan untuk mendesain solusi sistem berbasis pada kebutuhan yang didefenisikan dan pembuatan keputusan terhadap hasil analisis.

4. Implementasi, bertujuan untuk membangun, menguji dan menginstall sebuah sistem informasi yang dapat dipercaya.

5. Penggunaan, bertujuan untuk menjaga agar sistem tetap berjalan dengan produktif dan sistem dapat memiliki daya tahan selama bertahun-tahun (McLeod dan Schell, 2008).

\section{BlackBox Testing}

Menurut Maturidi (2012), pengujian black-box testing berfokus pada persyaratan fungsional Perangkat Lunak. Pengujian ini memungkinkan analisis sistem memperoleh kumpulan kondisi input yang akan mengerjakan seluruh keperluan fungsional program. Tujuan metode ini mencari kesalahan pada :

1. Fungsi yang salah atau hilang.

2. Kesalahan pada interface.

3. Kesalahan pada struktur data atau akses database.

\section{METODE PENELITIAN}

Tempat dan Waktu Penelitian

Penelitian dilakukan di Rumah Sakit Umum Daerah (RSUD) Wangaya Kota Denpasar pada bulan Juli 2017.

\section{Metode Pengumpulan Data}

Pengumpulan data dilakukan dengan melakukan observasi dan wawancara. Observasi adalah pengumpulan dat alapangan yang dilakukan dengan pengamatan langsung pada objek yang dituju. Observasi bertujuan untuk mendapatkan berbagai informasi tentang permasalahan pada bagian filing rekam medis di RSUD Wangaya Kota Denpasar. Wawancara dilakukan kepada Kepala Instalasi Rekam Medis di RSUD Wangaya Kota Denpasar dan juga kepada beberapa petugas filing dan petugas poli untuk memperoleh data yang diperlukan dalam pembuatan aplikasi.

\section{Analisis dan Perancangan Sistem}

Pada tahap ini diperlukan analisis permasalah secara mendalam dengan menyusun studi kelayakan.

1. Kelayakan teknis dilakukan dengan menganalisis kebutuhan perangkat keras dan perangkat lunak untuk melaksanakan proses yang diperlukan.

2. Operasional

Untuk mengoperasikan tracer medical record file berbasis PHP user harus bisa mengoperasikan sistem ini mulai dari 
login, registrasi rekam medis, pencarian rekam medis dan pemindahan rekam medis.
3. Desain Sistem (System Design)

Tahap-tahapan perancangan sistem dilakukan dengan :

a. Perancangan DFD (Data Flow Diagram). DFD mengilustrasikan bagaimana data mengalir melalui proses-proses yang saling tersambung pada aplikasi tracer medical record file.

- Context Diagram

Menggambarkan hubungan antara sistem dengan lingkungan luar sistem yang mempengaruhi operasi sistem.

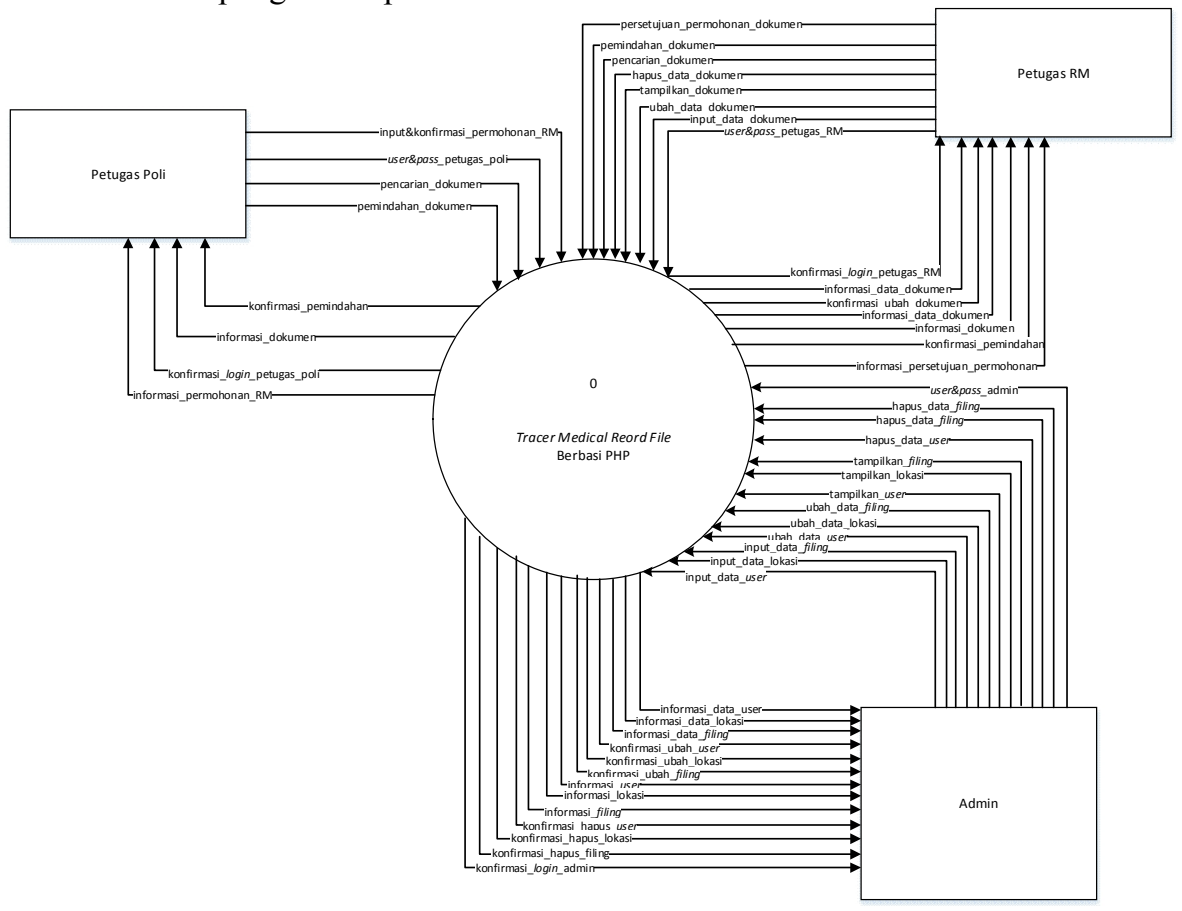

Gambar 1 Diagram Konteks

a. Perancangan Basis Data.

b. Perancangan ERD (Entity Relationship Diagram). ERD dibuat untuk mempermudah analisis dan perancangan.

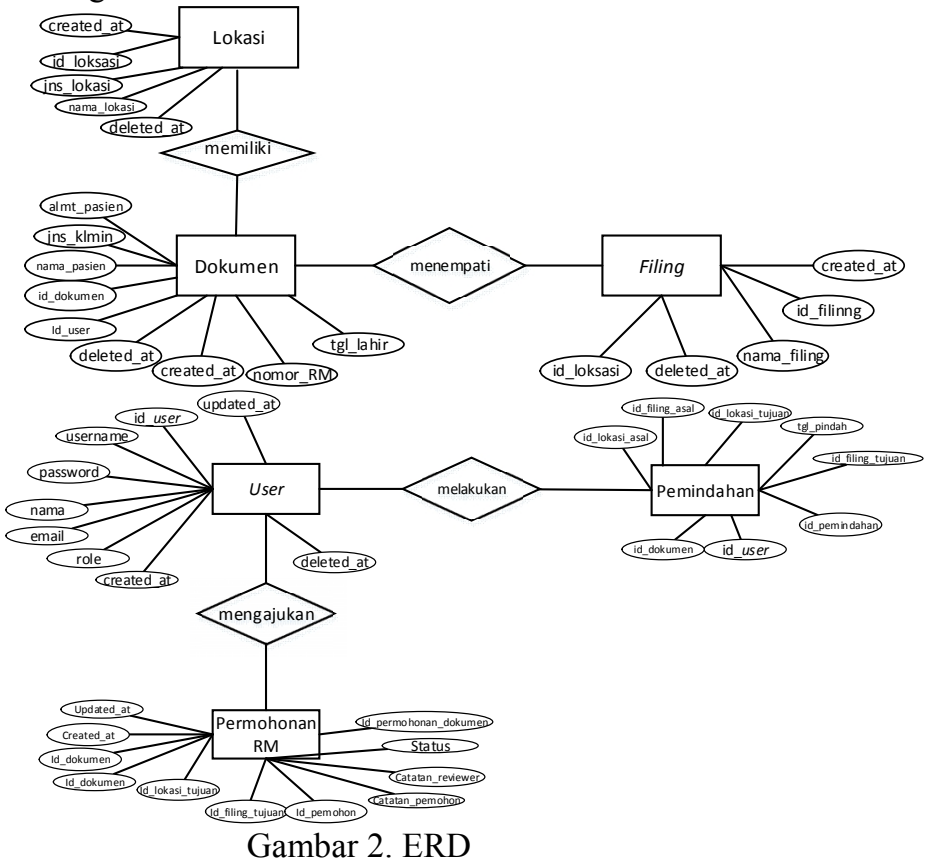


c. Perancangan User Interface, merupakan perancangan interface untuk input data dan rancangan untuk output data.

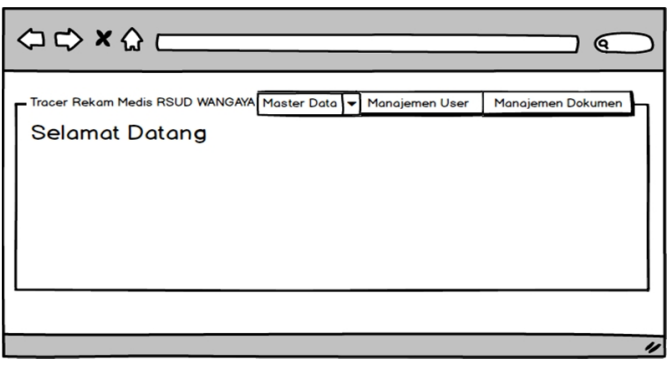

Gambar 3 Halaman Utama

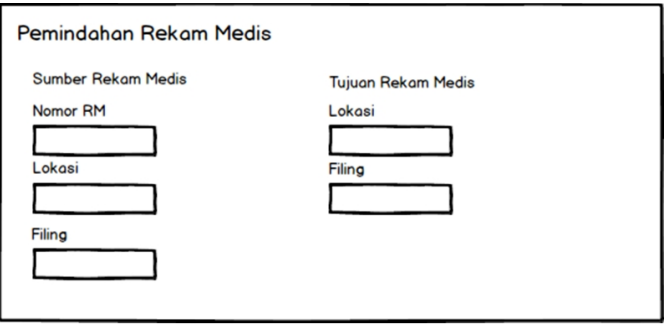

Gambar 5 Pemindahan Rekam Medis

\section{IMPLEMENTASI DAN PENGUJIAN \\ SISTEM}

Implementasi sistem

Implementasi sistem merupakan penerapan dan pengujian bagi sistem berdasarkan analisis dan perancangan yang telah dilakukan sebelumnya. Aplikasi tracer medical record file berbasis hypertext preprocessor (PHP) di Rumah Sakit Umum Daerah (RSUD) Wangaya Kota Denpasar menggunakan PHP sebagai bahasa pemrogramannya dan MySQL sebagai database, pembuatan database menggunakan phpmyadmin untuk mempermudah pembuatan database.

\section{Antar Muka Sistem (Interface)}

a. Login

Fungsi dari halaman login adalah untuk dapat masuk ke halaman utama dan menggunakan fasilitas yang ada didalam aplikasi tracer medical record file. Untuk login pengguna harus memasukkan username dan password. Jika pengguna memasukkan username dan password yang benar maka pengguna dapat langsung mengakses halaman utama.

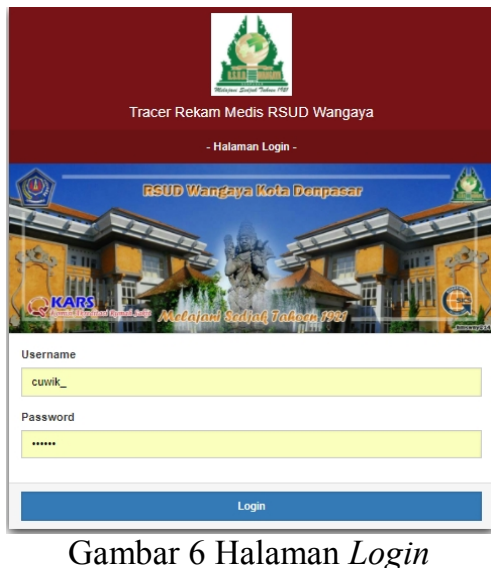

b. Tampilan Halaman Manajemen User

Pada halaman manajemen user menampilkan nama user, role, email, username, dan opsi. Untuk mengubah data user, dapat dilakukan mengklik "Edit" pada Opsi. Untuk dapat menghapus data user, dapat dilakukan dengan mengklik "Hapus" pada opsi. Apabila ingin melakukan pencarian user, dapat dilakukan dengan memasukkan kata kunci pada pencarian textbook pencarian data user. Data yang ditampilkan adalah data semua kategori sesuai dengan kata kunci yang diinputkan.

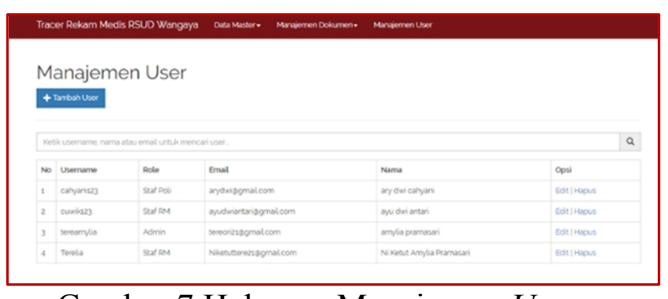

Gambar 7 Halaman Manajemen User

c. Tampilan Halaman Manajemen

Dokumen

Manajemen Dokumen memiliki dua menu yaitu pencarian dokumen dan permohonan dokumen. Pada halaman pencarian, menampilkan data rekam medis yaitu nomor rekam medis, nama pasien, tanggal lahir, jenis kelamin, alamat. Untuk dapat menghapus data dokumen, dapat dilakukan dengan mengklik "Hapus" pada Opsi. Untuk meregistrasi dokumen baru klik "Tambah Dokumen". 


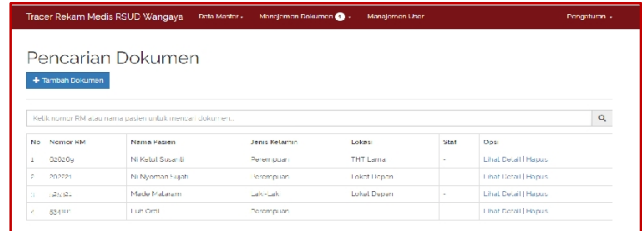

Gambar 8 Halaman Manjemen Dokumen

d. Tampilan Halaman Daftar Lokasi

Pada halaman daftar lokasi menampilkan nama lokasi dan jenis lokasi yang sudah terregistrasi. Untuk mengubah data lokasi, dapat dilakukan mengklik "Edit" pada Opsi dan untuk dapat menghapus data lokasi dapat dilakukan dengan mengklik "Hapus" pada Opsi. Untuk meregistrasikan lokasi baru klik "Tambah Lokasi”.

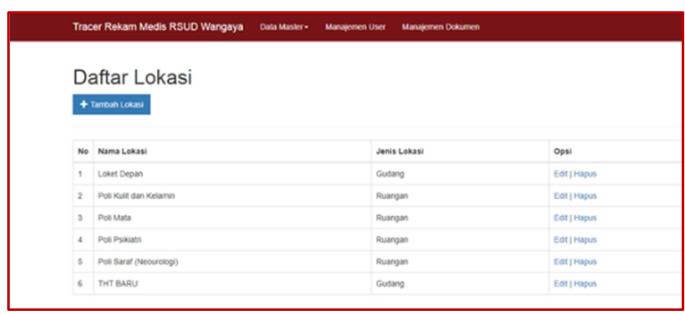

Gambar 9 Halaman Daftar Lokasi

e. Tampilan Halaman Daftar Filing

Pada halaman Daftar Filing menampilkan nama rak filing, dan nama lokasi rak filing tersebut. Untuk mengubah data filing dapat dilakukan mengklik "Edit" pada opsi dan untuk dapat menghapus data lokasi dapat dilakukan dengan mengklik "Hapus" pada Opsi. Untuk menambahkan filing baru klik "Tambah Filing"

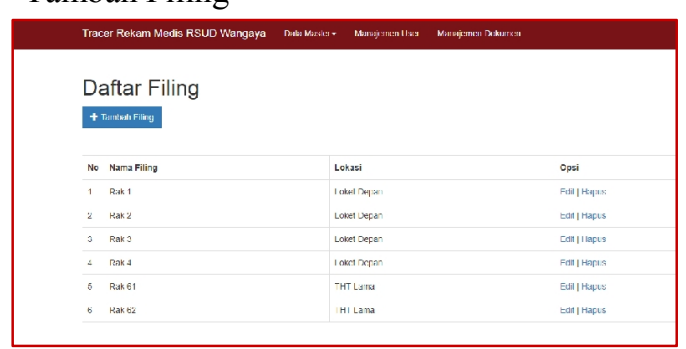

Gambar 10 Halaman Daftar Filing

f. Tampilan Halaman Pemindahan Rekam Medis

Pemindahan dilakukan dengan menginputkan lokasi dan filing pada field tujuan rekam medis. Button Pindahkan
Dokumen berfungsi untuk menyimpan data pemindahan.

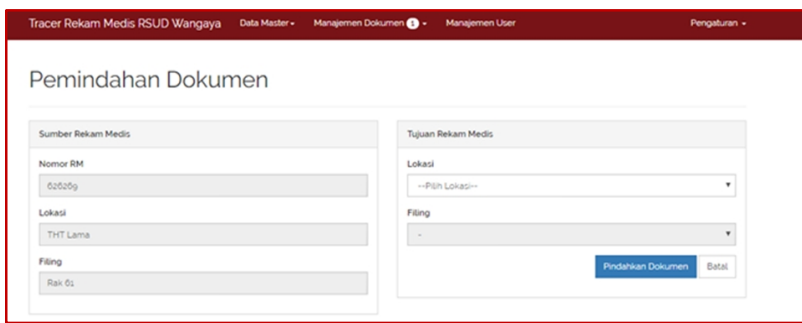

Gambar 11 Halaman Pemindahan Dokumen

\section{Simulasi Pengujian Sistem}

1. Seorang pasien bernama Tubagus Nugraha dengan nomor rekam medis pasien yaitu 345708. Berkunjung ke RSUD Wangaya untuk mendapatkan pelayanan di Poli Mata dan Poli Penyakit Dalam.

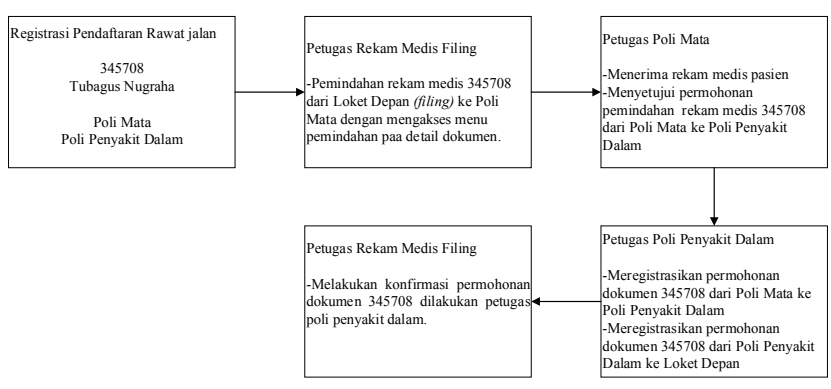

Gambar 11 Simulasi Pemindahan Rekam Medis Pasien

2. Petugas rekam medis bagian koder melakukan permohonan rekam medis atas nama Poppy Septia dengan nomor rekam medis pasien 505001 ke petugas rekam medis bagian filing.

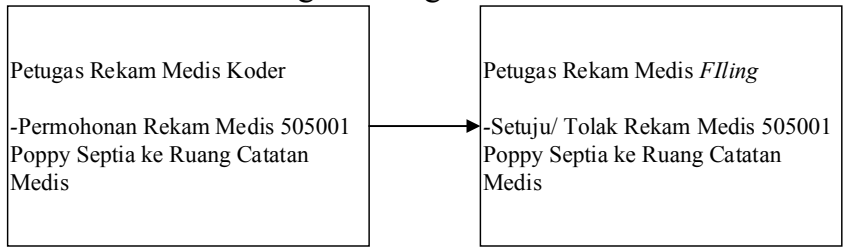

Gambar 12 Simulasi Permohonan Rekam Medis Pasien

\section{SIMPULAN}

Berdasarkan penelitian yang sudah dilakukan mengenai, perancangan dan implementasi dari skripsi yang berjudul "Rancang Bangun Aplikasi Tracer Medical Record File Berbasis Hypertext Preprocessor (PHP) di 
Rumah Sakit Umum Daerah (RSUD) Wangaya Kota Denpasar", maka didapatkan kesimpulan sebagai berikut :

Penelitian ini berhasil menghasilkan rancang bangun aplikasi tracer medical record file berbasis hypertext preprocessor (PHP) yang dapat digunakan untuk melacak dan memonitoring rekam medis yang keluar dan masuk rak penyimpanan di Rumah Sakit Umum Daerah (RSUD) Wangaya Kota Denpasar.

\section{DAFTAR PUSTAKA}

[1] Departemen Kesehatan Republik Indonesia. 2006. Pedoman

Penyelenggaraan dan Prosedur Rekam Medis Rumah Sakit (Revisi II). Jakarta.

[2] IFHIMA (International Federation of Health Information Management Associations). 2012. Module 7 Administration and Management of the Health Record Department. Education Module For Health Record Practice [Internet].

[3] Heryanto, A. 2010. Aplikasi Pelayanan Puskesmas Berbasis WEB: Studi Kasus Puskesmas Kec. Maja. Jakarta.

[4] Junaedi, F. 2005. Panduan Lengkap Pemrograman PHP Untuk Membuat Web Dinamis. Yogyakarta: PD. Anindya.

[5] Kadir, Abdul. 2003. Pengenalan Sistem Informasi. Yogyakarta : Andi.

[6] Maturidi, Ade Djobar. 2012. Metode Penelitian Teknik Informatika. Yogyakarta: Deepublish.

[7] McLeod, R and Schell, G 2008. Sistem Informasi Manajemen, Edisi 10. Jakarta: Selemba Empat.

[8] Menteri Kesehatan Republik Indonesia. 2008. Tentang Standar Pelayanan Minimal Rumah Sakit. Jakarta : Kementrian Kesehatan RI.

[9] Sidik, B., dan Pohan, I.H. 2002. HTML dan XML. Bandung : Informatika.

[10] Sukaesih, F. 2008. Hubungan Karakteristik Petugas dengan Kinerja Petugas Rekam Medik di Rumah Sakit Umum Daerah Rokan Hulu. Tesis.
Pasca Sarjana. Universitas Sumatera

Utara, Medan.

[11] Sulhan. Moh. 2006. Pengembangan Aplikasi Barbasis Web dengan PHP dan ASP. Malang: Gava Media.

[12] Suryana, Taryana \& Koesheryatin. 2014. Aplikasi Internet Menggunakan HTML, CSS \& Java Script. Jakarta: PT Elex Media Komputindo.

[13] Suyanto. 2006. Dasar-dasar Perancangan Web Dari Pemula Sampai Mahir. Jakarta : PT. Elex Media Komputindo.

[14]Peraturan Mentri Kesehatan Republik Indonesia. 2008. No. 269/Menkes/Per/III/2008 Tentang Rekam Medis.

[15]Peraturan Menteri Kesehatan Republik Indonesia. Nomor 55 Tahun 2013. Tentang Penyelenggaraan Pekerjaan Perekam Medis.

[16]Peraturan Menteri Kesehatan Republik Indonesia. Nomor 56 Tahun 2014. Tentang Klasifikasi dan Perizinan Rumah Sakit.

[17]Peraturan Menteri Kesehatan Republik Indonesia. Nomor 82 Tahun 2013. Tentang. Sistem Informasi Manajemen Rumah Sakit.

[18]Utami A.S. 2016. Perancangan Tracer Berbasis Elektronik Di Filing Rawat Jalan RSUD RAA SOEWONDO PATI Tahun 2016. Semarang. 